\title{
NOTE
}

\section{Detection of grey seal Halichoerus grypus DNA in attack wounds on stranded harbour porpoises Phocoena phocoena}

\author{
Judith D. L. van Bleijswijk ${ }^{1, *}$, Lineke Begeman ${ }^{2}$, Harry J. Witte ${ }^{1}$, \\ Lonneke L. IJsseldijk ${ }^{2}$, Sophie M. J. M. Brasseur ${ }^{3}$, Andrea Gröne ${ }^{2}$, Mardik F. Leopold ${ }^{3}$ \\ ${ }^{1}$ Royal Netherlands Institute for Sea Research, PO Box 59, 1790 AB Den Burg, Texel, the Netherlands \\ ${ }^{2}$ Department of Pathobiology, Faculty of Veterinary Medicine, Utrecht University, Yalelaan 1, 3584 CL Utrecht, the Netherlands \\ ${ }^{3}$ Wageningen IMARES, Department of Ecosystems, PO Box 167, 1790 AD Den Burg, Texel, the Netherlands
}

\begin{abstract}
DNA was analysed from external wounds on 3 dead harbour porpoises Phocoena phocoena that were stranded in the Netherlands. Puncture wounds as well as the edges of large open wounds were sampled with sterile cotton swabs. With specific primers that target the mtDNA control region of grey seal Halichoerus grypus, a 196 bp DNA fragment was amplified from 4 puncture wounds. Sequencing of the fragments confirmed the presence of grey seal DNA in the puncture wounds. DNA sequences differed between the cases, implying that 3 individual grey seals were involved. As 8 control swabs from intact skin and the transport bag as well as 6 swabs from open wounds on the same harbour porpoises were all negative, contamination with environmental DNA is considered unlikely. The results provide a link between strandings of mutilated harbour porpoises and recent observations of grey seals attacking harbour porpoises. Ours is the first study to use forensic techniques to identify DNA in bite marks from carcasses recovered from the marine environment. This approach can be extended to identify other marine aggressors, including cases involving persons mutilated at sea.
\end{abstract}

KEY WORDS: mtDNA · Diagnostic PCR · North Sea · Inter-species interaction · Predation Mutilation · Forensic analysis

\section{INTRODUCTION}

Increasing numbers of harbour porpoises Phocoena phocoena have stranded around the North Sea (Peltier et al. 2013). A particular feature of many porpoises stranded in the south-eastern North Sea is that they show severe, sharp-edged mutilations. Several causes for these mutilations have been suggested, such as ship strikes or fisheries by-catch (Camphuysen \& Siemensma 2011). Recently, predatory or scavenging grey seals Halichoerus grypus have been held responsible based on morphological analyses of lesions on 2 porpoise carcasses (Haelters et al. 2012) and 3 field observations of grey seals feeding on harbour porpoises (Bouveroux et al. 2014). Leopold et al. (in press a) reported that most of the mutilated porpoises were juveniles in good nutritional condition (thick blubber layer) with full stomachs. Evidence that grey seals are truly responsible for killing the harbour porpoises that subsequently become stranded can only be gained from a combination of detailed pathology from a large number of carcasses (Leopold 
et al. in press b) and from DNA studies. The latter can, in theory, take 2 approaches. Porpoise DNA in the alimentary tract of grey seals would prove that these seals have consumed (parts of) porpoises, whereas demonstrating grey seal DNA in the wounds of the mutilated porpoises would prove that the wounds were inflicted by grey seals.

In terrestrial settings, forensic DNA analyses has been successfully used to identify the species as well as the sex and individual identity of the predator (Williams et al. 2003, Blejwas et al. 2006). However, in situations in which a body has been submerged in water, this technique has been much less successful. In fact, we could only find one case where the DNA of a perpetrator was found in bite marks on a human body found in fresh water (Sweet \& Shutler 1999), and we were unable to find a single case from the marine environment. Here, we report forensic DNA analyses of wounds on 3 stranded harbour porpoises. We developed a diagnostic PCR that provides a product when mitochondrial DNA of grey seal is present. The test was designed in such a way that DNA of the victim (Phocoena phocoena) and of other potential predators (Phoca vitulina, Orcinus orca) or scavengers (Canis lupus familiaris, Vulpes vulpes) would give negative results. Forensic science protocols (Alaeddini et al. 2010) were followed in order to prevent contamination with grey seal DNA.

\section{MATERIALS AND METHODS}

\section{Primer design}

For the development of a diagnostic PCR for grey seal, sequences of the mtDNA control region of grey seal, the sympatric harbour seal Phoca vitulina, the harbour porpoise, and various other marine mammals and terrestrial scavengers were obtained from GenBank. For grey seal, we selected the data of Graves et al. (2009) re-edited by Fietz et al. (2013). In addition, new data were generated using the primer pair ThrL16272 and DLH16750 (Stanley et al. 1996) on DNA extracts of 8 grey seals (GenBank accession numbers KM053398-KM053405) and 97 faecal samples of grey seals from various locations in the
Dutch North Sea and Wadden Sea (GenBank accession numbers KM066992-KM067088). A multiple sequence alignment was created (Fig. S1 in the Supplement at www.int-res.com/articles/suppl/m513 p277_supp.pdf), and lists of species-specific primers were generated by the automated probe design option in 'ARB' (Ludwig et al. 2004).

Candidate primer sequences were checked for false matches with non-target species in GenBank using the Basic Local Alignment Search Tool (BLAST). Efficiency and specificity for grey seal was further confirmed for the primer pair HG_F1 (5'-CTT CGT GCA TTG CAT GCT-3') and HG_R1 (5'-CAT GGT GAC TAA GGC TCT-3') in PCRs on DNA extracts of tissues and faeces from grey and harbour seals.

\section{Forensic test}

Forensic DNA analyses were done on 3 stranded harbour porpoises found at 3 different locations along the Dutch coastline (in August, October and December 2013) and showing potential bite marks. On the beach, the carcasses were wrapped in clean plastic bags by transporters who wore clean clothes. Within $6 \mathrm{~h}$ after discovery, the carcasses were investigated at Utrecht University in a laboratory that had not contained seal specimens for at least $10 \mathrm{~d}$ prior. Presumed attack wounds, puncture lesions and 
edges of large open lesions were sampled with dry sterile cotton swabs (Table 1). Additional swabs were wiped over the intact skin of one of the porpoises and over the inside of the plastic bag used for transport. Negative control swabs were simply released from their packaging, in close proximity to the porpoise being autopsied, and processed along with the swabs taken from wounds. Swabs were individually packed, stored frozen at $-20^{\circ} \mathrm{C}$ and transported to the Royal Netherlands Institute for Sea Research on the island of Texel for DNA analyses.

DNA was extracted and purified from the swabs using the QIAamp Investigator kit (Qiagen) following the protocol for surface and buccal swabs. Carrier RNA was not added because the total amount of DNA (from harbour porpoise, bacteria and predator combined) in test samples exceeded $2 \mathrm{ng} \mathrm{\mu l}^{-1}$. All extractions were done at overpressure in a certified ISO-6 clean lab, well separated from the PCR lab (via a sluice and situated on a different floor), where no other marine samples had been located or processed for at least 3 wk prior. DNA from each swab was eluted from silica columns in $40 \mu \mathrm{l}$ of buffer, quantified with a fluorometer and run on $1 \%$ agarose gels to verify the quality of the extract.

Fragments of $196 \mathrm{bp}$ of the mitochondrial control region were amplified from $2 \mu \mathrm{l}$ of DNA extract in a $50 \mu \mathrm{l}$ PCR using the newly designed primers specific for grey seal (HG_F1 and HG_R1). The reaction mix contained $1 \times$ buffer, dNTPs, forward and reverse primers, BSA and Biotherm Polymerase. In a first PCR step, we ran 40 cycles of $20 \mathrm{~s}$ at $94^{\circ} \mathrm{C}$, $20 \mathrm{~s}$ at $50^{\circ} \mathrm{C}$ and $30 \mathrm{~s}$ at $72^{\circ} \mathrm{C}$. Subsequently, in a second PCR under similar conditions, $1 \mu \mathrm{l}$ of product of the first PCR was re-amplified with 15 additional cycles. All samples from stranded porpoises were analysed in 4-fold. Negative PCR controls were run, but positive controls, i.e. DNA extracts of grey seal DNA, were not included, to prevent cross contamination. All PCR products were loaded on $2 \%$ agarose gels along with a size marker (SmartLadder or SmartLadder SF) and stained with SybrGold. The presence of bands was scored visually. DNA was extracted from the bands (Qiagen Gel extraction kit) and concentrated (Qiagen Minelute kit). PCR products were sequenced with forward and reverse primers by BaseClear (Leiden). Consensus sequences were BLAST searched and compared in a multiple alignment as specified in the primer design section above. New sequences obtained from puncture lesions on stranded harbour porpoises were submitted to GenBank (under accession numbers KJ863396-9).

\section{RESULTS}

Two out of the 9 harbour porpoise wound swabs (S8 and S9 from porpoise Pp2, Table 1) showed amplification products with grey seal-specific primers after the first PCR (40 cycles), and 2 more swabs (S3 from Pp1 and S18 from Pp3) after the second PCR (15 additional cycles). PCR replicates (4-fold) always showed consistent results (triplicates are shown in Fig. S2 in the Supplement). The positive results were obtained from puncture lesions with underlying haemorrhages on 3 different harbour porpoises. Swabs from edges and corners of open lesions did not provide PCR products, nor did swabs from intact skin or negative control swabs, making contamination with environmental DNA highly unlikely. Sequencing the PCR products obtained from the puncture wounds delivered good quality reads from both the forward and the reverse primer (chromatograms in Fig. S3 in the Supplement). Consensus sequences with primer sequences trimmed off (no ambiguities, 134-161 bp) matched sequences of the control region of grey seals (Fig. 1). The grey seal sequences differed among the 3 cases, implying that 3 different grey seal individuals had attacked the harbour porpoises.

\section{DISCUSSION}

We assume that the grey seal DNA detected in wounds on 3 stranded mutilated harbour porpoises came from saliva remaining after a grey seal bite (Haelters et al. 2012, Leopold et al. in press b). Of the 9 wounds that were swabbed in total, only 4 were positive. These were all relatively small and deep punctures that may have been pressed closed quickly after the bite. Salivary DNA of the perpetrator is more likely to be preserved in such wounds than in larger, more open lesions due to the heavier bleeding and the open structure of the latter, which allows rinsing by sea water. Indeed, the other wounds that were swabbed were more severe and open in structure, and all came up negative. These results, together with the negative results for 1 intact skin swab and 8 blanks, enable us to exclude environmental DNA (DNA freely floating in sea water) or contamination as the source of the positive results.

For future cases of stranded, mutilated harbour porpoises, we recommend swabbing puncture lesions, to objectively score inter-species interactions. Additional histological observation of haemorrhages in tissues underlying these puncture lesions can provide evidence for either attacks on live animals 
Fig. 1. Distance tree (ARB neighbour joining) of 354 positions of the mtDNA control region. mtDNA from bite marks on stranded Phocoena phocoena was added to this tree via ARB parsimony and is indicated in bold with swab number (S), Phocoena phocoena number (Pp) and GenBank accession number. Scale bar indicates relative amount of substitutions. Numbers associated with groups indicate the number of sequences in that group. Hg: grey seal Halichoerus grypus. Haplotype numbers (e.g._H6) are according to Fietz et al. (2013). Note that the sequences obtained from 2 different bite marks on porpoise Pp2 are similar but differ from the sequences obtained from porpoises Pp1 ( 2 bases) and Pp3 (1 base)

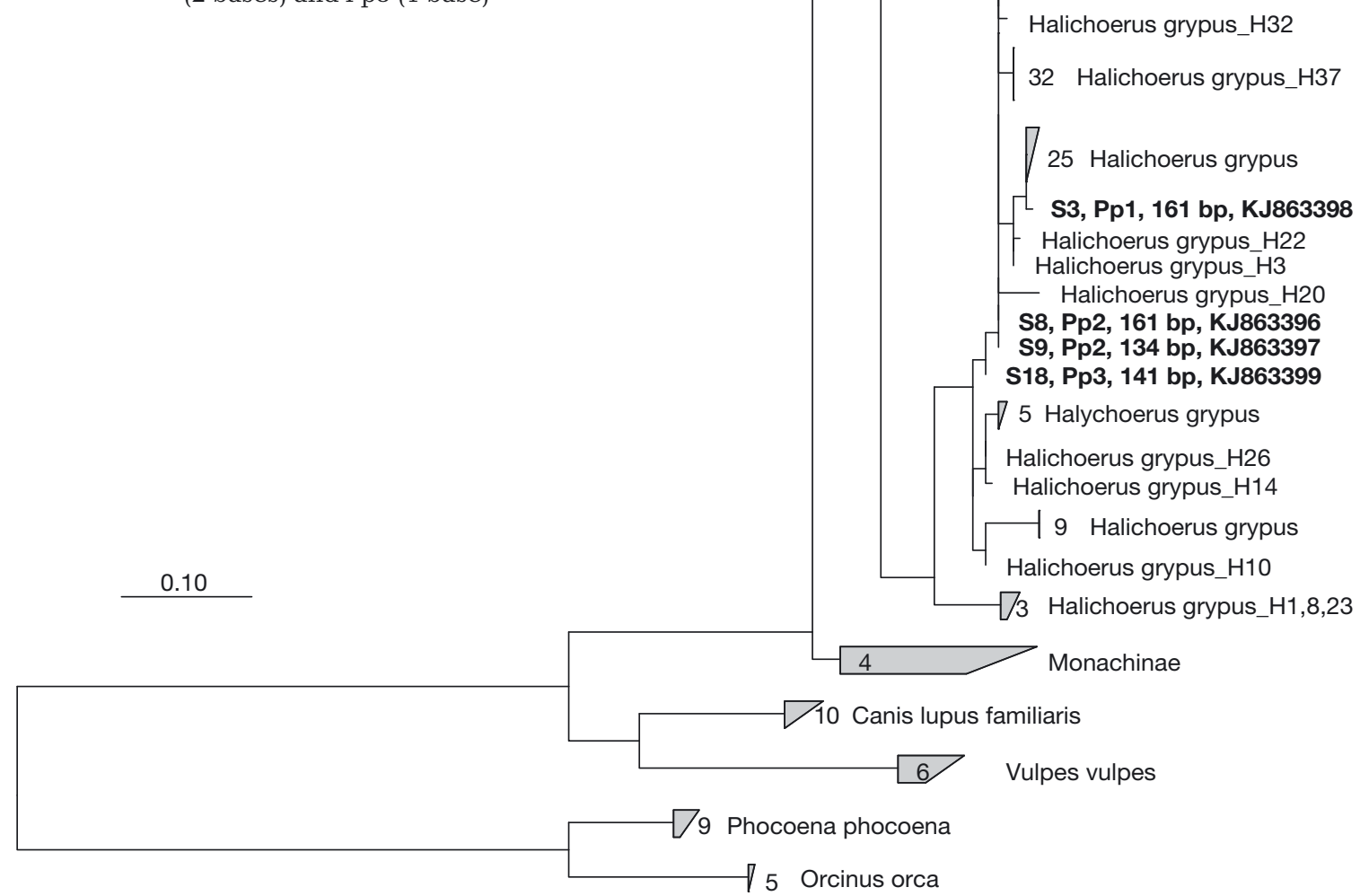

(haemorrhage present) or scavenging (haemorrhage absent). With these techniques combined, it is possible to discriminate between human-induced mutilation and inter-species aggression.

Our study is the first successful application of a forensic DNA technique in the marine environment and could be extended to identify other marine aggressors (Bolt et al. 2009, Estes et al. 2009), including cases involving persons mutilated at sea (Sweet \& Shutler 1999).

Acknowledgements. We thank Stefan Schouten for valuable advice, Nicole Bale for improving the grammar of the manuscript, Hans Malschaert for ARB and Linux support, Okka Jansen and Jasper de Goey for lab work on primer testing and sequence preparation and Jaap van der Hiele, Arnold Gronert and Kees Kooimans for collecting and transporting the carcasses. The Dutch Ministry of Economic Affairs financed the forensic tests, under project HD3456.

\section{LITERATURE CITED}

Alaeddini R, Walsh SJ, Abbas A (2010) Forensic implications of genetic analyses from degraded DNA: a review. Forensic Sci Int Genet 4:148-157

Blejwas KM, Williams CL, Shin GT, McCullough DR, Jaeger MM (2006) Salivary DNA evidence convicts breeding male coyotes of killing sheep. J Wildl Manag 70: 1087-1093

Bolt HE, Harvey PV, Mandleberg L, Foote AD (2009) Occurrence of killer whales in Scottish inshore waters: temporal and spatial patterns relative to the distribution of declining harbour seal populations. Aquat Conserv 19: 671-675

Bouveroux T, Kiszka JJ, Heithaus MR, Jauniaux T, Pezeril S (2014) Direct evidence for gray seal (Halichoerus grypus) predation and scavenging on harbor porpoises (Phocoena phocoena). Mar Mammal Sci 30:1542-1548

Camphuysen CJ, Siemensma ML (2011) Conservation plan for the harbour porpoise Phocoena phocoena in The Netherlands: towards a favourable conservation status. 
NIOZ Report 2011-07. Royal Netherlands Institute for Sea Research, Texel

Estes JA, Doak DF, Springer AM, Williams TM (2009) Causes and consequences of marine mammal population declines in southwest Alaska: a food-web perspective. Philos Trans R Soc Lond B Biol Sci 364:1647-1658

Fietz K, Graves JA, Olsen MT (2013) Control control control: a reassessment and comparison of GenBank and chromatogram mtDNA sequence variation in Baltic grey seals (Halichoerus grypus). PLoS ONE 8:e72853

Graves JA, Helyar A, Biuw M, Jussi M, Jussi I, Karlsson O (2009) Microsatellite and mtDNA analyses of the population structure of grey seals (Halichoerus grypus) from three breeding areas in the Baltic Sea. Conserv Genet 10:59-68

Haelters J, Kerckhof F, Janiaux T, Degraer S (2012) The grey seal (Halichoerus grypus) as a predator of harbour porpoises (Phocoena phocoena)? Aquat Mamm 38:343-353

Leopold MF, Begeman L, Heße E, van der Hiele J and others (in press a) Porpoises: from predators to prey. J Sea Res

Editorial responsibility: Per Palsbøll,

Groningen, the Netherlands
Leopold MF, Begeman L, van Bleijswijk JDL, IJsseldijk LL, Witte HJ, Gröne A (in press b) Exposing the grey seal as a major predator of harbour porpoises. Proc R Soc B

Ludwig W, Strunk O, Westram R, Richter L, Meier H and others (2004) ARB: a software environment for sequence data. Nucleic Acids Res 32:1363-1371

Peltier H, Baagøe HJ, Camphuysen CJ, Czeck R, Dabin W and others (2013) The stranding anomaly as population indicator: the case of harbour porpoise Phocoena phocoena in North-Western Europe. PLoS ONE 8:e62180

Stanley HF, Casey S, Carnahan JM, Goodman S, Harwood J, Wayne RK (1996) Worldwide patterns of mitochnondrial DNA differentiation in the harbor seal (Phoca vitulina). Mol Biol Evol 13:368-382

> Sweet D, Shutler GG (1999) Analysis of salivary DNA evidence from a bite mark on a body submerged in water. J Forensic Sci 44:1069-1072

Williams CL, Blejwas K, Johnston JJ, Jaeger MM (2003) A coyote in sheep's clothing: predator identification from saliva. Wildl Soc Bull 31:926-932

Submitted: April 28, 2014; Accepted: August 18, 2014 Proofs received from author(s): October 10, 2014 